\title{
タイヤ用カーボンブラックと トライボロジー(摩擦・摩耗)特性
}

\section{曽 根 一 袥*}

\section{1.はじめに}

カーボンブラック (以下， $\mathrm{CB}$ と略記) を充てん することによってゴムの弾性率，破断強度，耐摩 耗性等は大幅に増大する. CBに要求される.性能は 年々厳しくなっており，タイヤ用CBについても， タイヤニーズの高度化によりトラクション，スキ ッド性等の摩擦性能，耐摩耗性，および低七ステ リシス化の高次バランスが求められている。本稿 ではこれらに及ぼすCBの影響について概説する。 また, 最適な耐摩耗性を与えるCB／ゴム複合体の 相互作用を考察し「スクラムモデル として提案 を試みる。

なお, 標記テーマを議論する上でCBの実像に迫 ることは需要なことである。，そこで本題に入る前 にCBの最近のキャラクタリゼーションについて若 干紙面を割くことを御了解いただきたい.

\section{2. カーボンブラック(CB)について}

$\mathrm{CB}$ は炭素原子から構成される一次粒子が三次元 的に融着したもので，最小単位はアグリゲートと 呼ばれる(図 1 )。従来, この一次粒子径とストラ クチャー, 表面性状が $\mathrm{CB}$ の大特性といわれてき た. しかし最近では, 実質的に表 1 の五大特性で 議論されることが多い。これは従来の三大特性に アグリゲート形状・分布を加え, 表面性状を性格 の異なる二つに分割したものである．表 1 にゴム に充てんした場合のそれぞれの耐摩耗性向上方向 と, 摩擦係数と正相関する $\tan \delta の$ 増大方向を示し た.これらのデータの一部は 3 項以下で紹介する. ここでアグリゲート形状・分布，表面性状につい て若干説明を加えておく。アグリゲートの大きさ

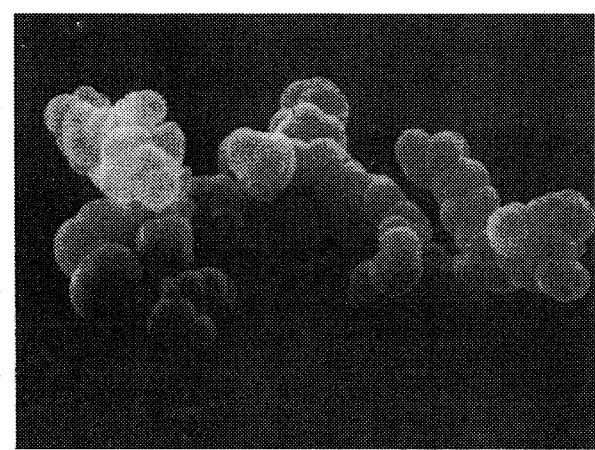

図 1 CBアグリゲートの電子顕微鏡写真

分布については遠心沈降式粒度分布測定装置 (DCF)の普及によりストークス径として広く測定 されている.一方, 最近ではその形状も解析され， Herdら ${ }^{1 \sim 3)}$ はアグリゲートの形状を分類している(図 2).またGerspacher ら ${ }^{4)}$ やDolleら ${ }^{5}$ はフラクタル 次元による解析を試みている.

図 3 にはゴム中でのCB凝集体強度分布推定図 ${ }^{6}$ を示した。アグリゲート強度はゴム配合物の摩耗

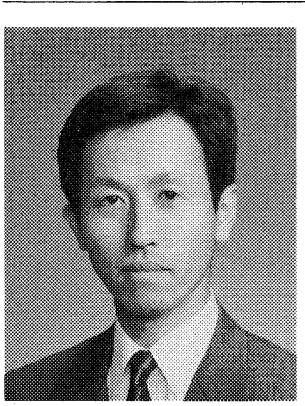

* 三菱化学株式会社 四日市 総合研究所 ( 5510 四日市 市東邦町1）主任研究員. 昭和 56 年, 九州大学大学院 総合理工学研究科修了. 同 年, 三菱化成㑣入社, 横浜 総合研究所配属. 昭和61年 より同社四日市工場開発研 究所 (平成 6 年, 三菱油化 (株)と合併し, 三菱化学(侏四 日市総合研究所となる) 勤 務. ゴム, カーボンブラック関係の研究, 開発に従事. 〈趣味〉将棋 


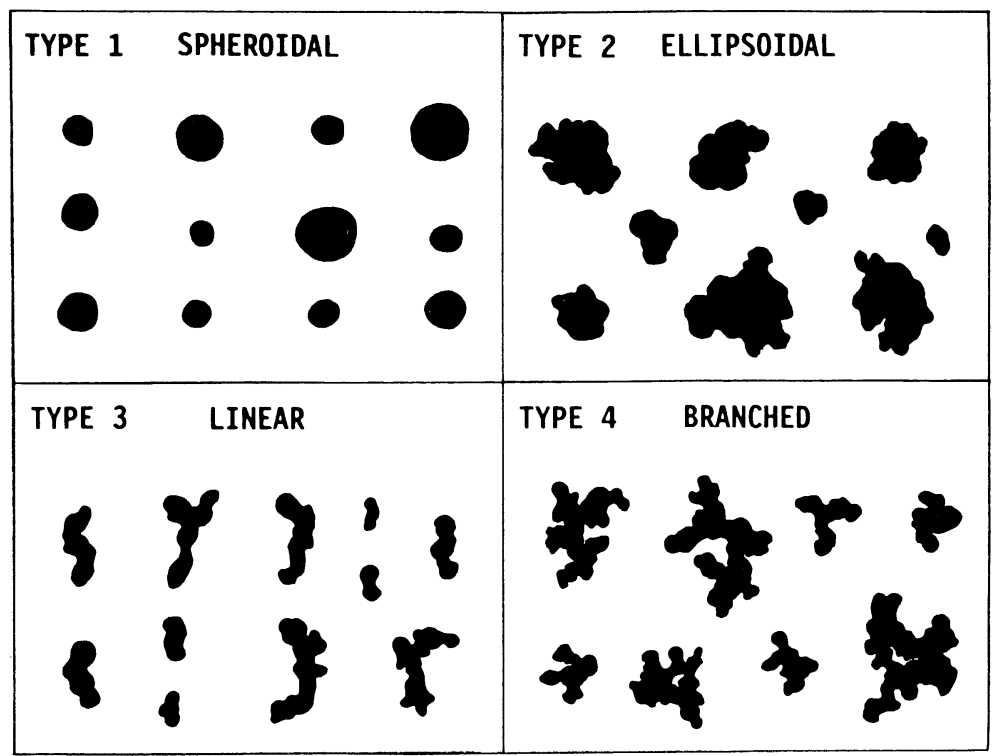

図 2 CBアグリゲートの形状分類

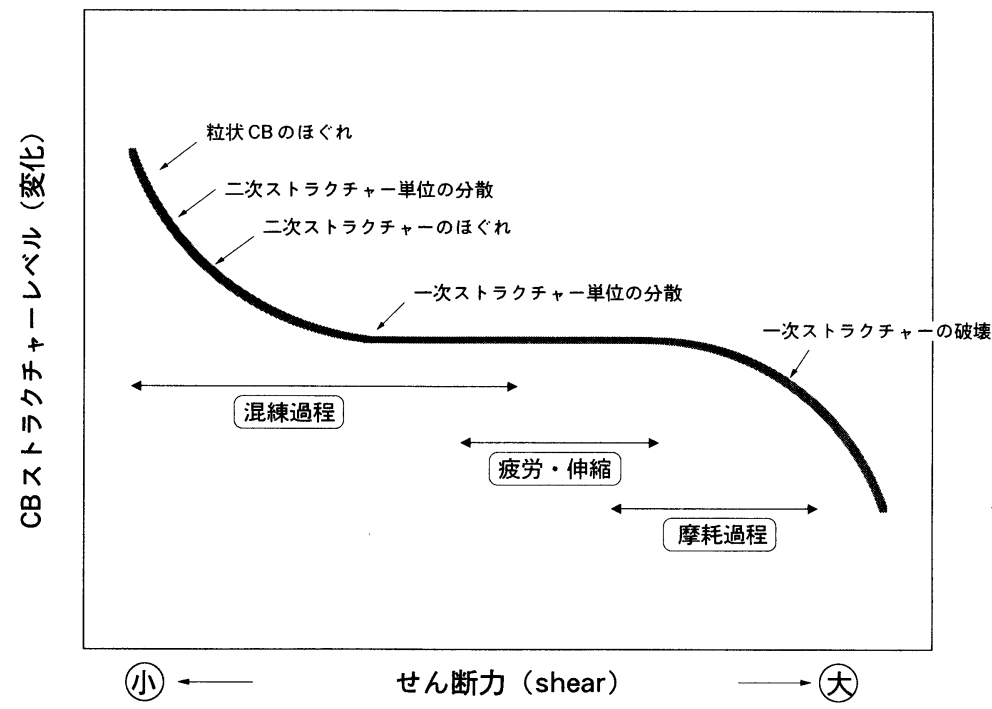

図 3 カーボンブラック凝集体強度分布推定困

特性と直接には関与しないと考えられる.しかし， 摩耗過程でのみアグリゲート（一次ストラクチャ 一）が破壊される7)ことは興味深い.

表面性状については，最近DonnetらがSTM (Scanning Tunneling Microscopy) によりCBの 表面構造を観察している。それに基づき，新しい
$\mathrm{CB}$ 表面モデル8,9)（図4下）を提案した。更に想像 以上に表面の凹凸が大きい状態も観察された（図 5 上).これより図 5 下に示すようなポリマー鎖の 吸着モデルを提案している ${ }^{10)}$. また, GoritzらはAFM (Atomic Force Microscopy) を用いCB表面構造 を解析している ${ }^{11)}($ 図 6 ). これら一連の解析はCB 
カーボンブラックー次粒子

初期モテル
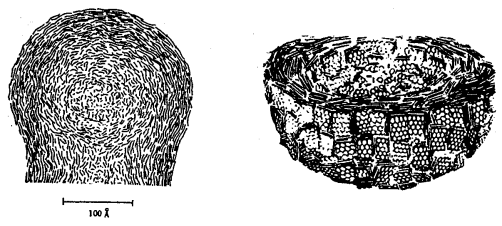

Heckmann ('68)

Hess ('68)

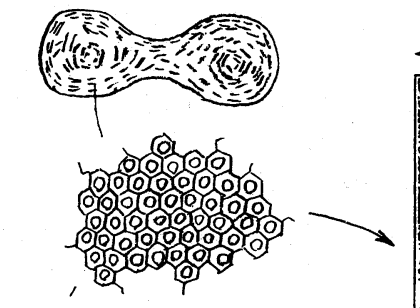

数 $10 \sim 50$ 環以上の集合体

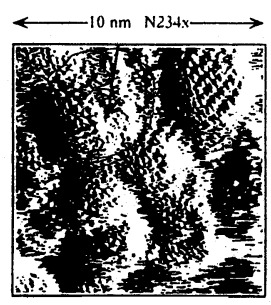

トンネル顕微鏡像
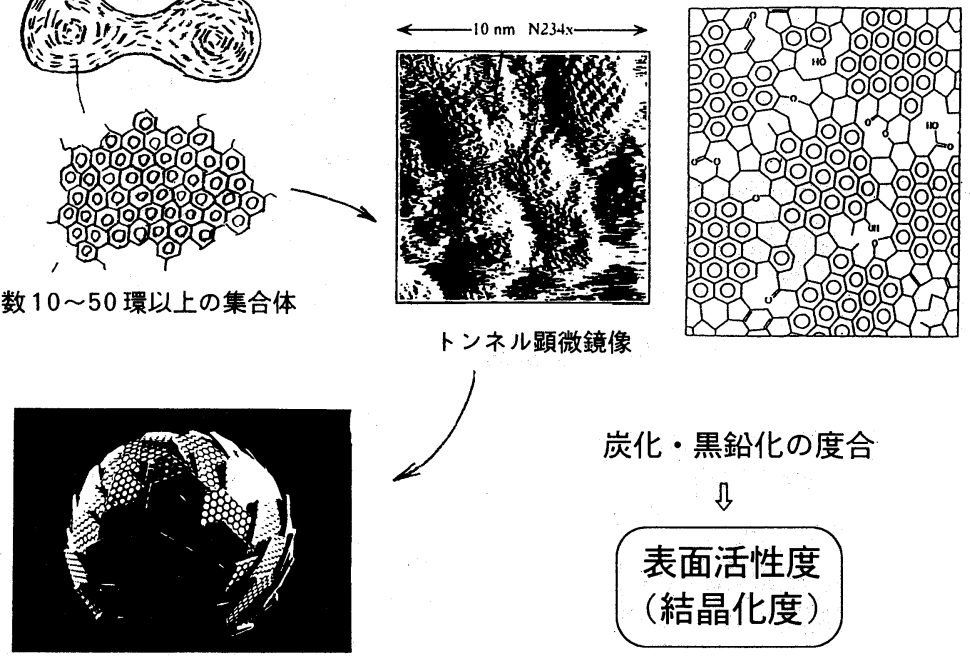

炭化・黑鉛化の度合

ת

\section{表面活性度 (結晶化度)}
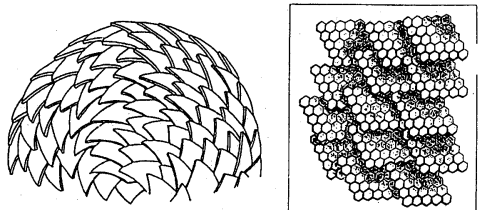

\section{$\mathrm{H}_{2}$ 量}

真比重

Lc

$\mathrm{T} \%$

$\mathrm{N}_{2} \mathrm{SA} / \mathrm{IA}$

新しい一次粒子モデル

etc.

図 4 CB表面性状「新しい一次粒子表面モデル」

とゴムとのインタラクション解明に大きく寄与す るものと考えられる.

\section{3.ゴム配合物の摩耗に対するCBの影響}

ゴムにCBを配合すると耐摩耗性は大幅に向上する。 このCBによる耐摩耗性向上の最大の因子は弾性率の 増加に基づく局部ゆがみの低下であるといわれてい る ${ }^{12)}$.ゴムの摩耗機構はアブレシブ摩耗や疲労摩耗な ど数種に分類されているが, 多くの場合複雑に絡み合
っている.以下に摩耗に対する $\mathrm{CB}$ の影響を考察す るが, 過酷度を考慮することも重要である。

\section{1 一次粒子径とストラクチャー, およびCB}

\section{配合量の影響}

一般に一次粒子径が小さくなるほど，すなわち 比表面積が大きいほど，また高ストラクチャーほ ぞ耐摩耗性は向上することが知られている（ただ し比表面積には最適值あり).これらは過酷度の影 響を大きく受け，低過酷度の場合には一次粒子径 


\begin{tabular}{|c|c|c|c|}
\hline CB五大特性 & 評 価 法 & $\begin{array}{c}\text { 耐摩耗性 } \\
\text { 方 向 }\end{array}$ & $\begin{array}{c}\tan \delta \\
\Delta \text { 方向 } \\
\text { (摩擦係数 } \\
\text { 『方向) }\end{array}$ \\
\hline $\begin{array}{l}\text { (1)比表面積 } \\
\text { (一次粒子径) }\end{array}$ & $\begin{array}{l}\mathrm{N}_{2} \mathrm{SA} \\
\mathrm{IA} \\
\mathrm{CTAB}\end{array}$ & 大 & 大 \\
\hline (2)ストラクチャー & $\begin{array}{l}\text { DBP } \\
24 \mathrm{M} 4 \mathrm{DBP}\end{array}$ & 高 & 低 \\
\hline \multirow{2}{*}{$\begin{array}{c}\text { (3)アグリゲート(凝集体) } \\
\text { 分布と形状 }\end{array}$} & DCF特性 & シャープ & シャープ \\
\hline & 異方性 & - & - \\
\hline $\begin{array}{l}\text { (4)表面活性度 } \\
\text { (結晶化度) }\end{array}$ & $\begin{array}{l}\mathrm{N}_{2} \mathrm{SA} / \mathrm{IA} \\
\mathrm{H}_{2} \text { 量, 真比重 } \\
\mathrm{T} \% \text {, etc }\end{array}$ & 大 & 小 \\
\hline $\begin{array}{l}\text { (5)表面ラフネス } \\
\text { (多孔度) }\end{array}$ & $\mathrm{N}_{2} \mathrm{SA}-\mathrm{CTAB}$ & 少 & 多 \\
\hline
\end{tabular}
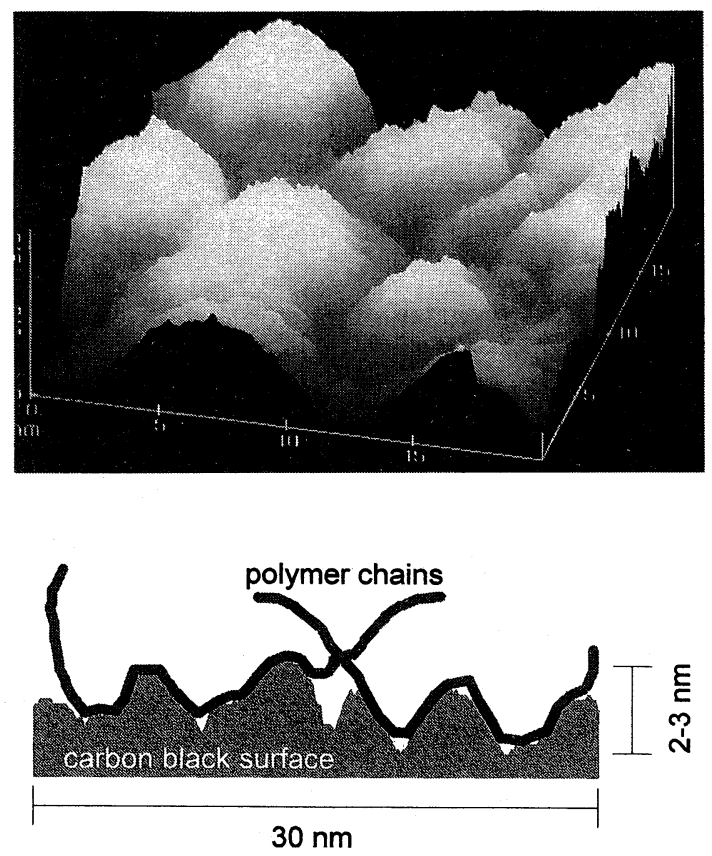

図 5 CB表面のSTM像とポリマー鎖の吸着モデル

に依存し，高過酷度の場合にはストラクチャーの 影響が大きくなる(一例を図 7 に示す)。これは摩 耗機構の違いに起因するものと考えられる. Shieh ら ${ }^{13)}$ はCB量が一定の配合ではラボ, 実走ともに最 高の耐摩耗性を与える比表面積があり(図 8 ), あ まり比表面積が大きくなると以下の理由で耐摩耗 性が劣ると説明している：発熱上昇, 分散悪化,

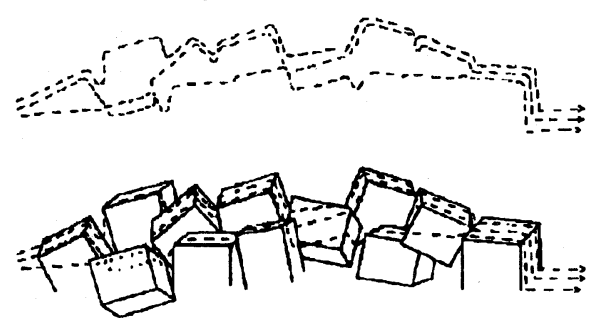

図 6 AFMによるCB表面解析

ポリマー鎖の過度の変形.

同様の実験を行った結果, 湿式分散法CBマス夕 一バッチ (WMB) を用いた系では耐摩耗性の最適 ピークは高比表面積側にシフトした6) (図 9$)$ 。こ れはCB分散度の向上などが関与しているものと考 えられる。

CB配合量にも最適な耐摩耗性を与える量が存在 する.この最適配合量は比表面積の大きいCBほど 低配合側にシフトする $\left(\right.$ 図10) ${ }^{13)}$.

最近, Tokitaら ${ }^{14)}$ は立方格子モデルを用いアグ リゲート間距離を求める式(1)を導いている。この 式は凝集体形状並びに分布ファクターとオクルー

$$
\begin{aligned}
& \mathrm{S}=\mathrm{f} \cdot \operatorname{Dst}\left[\frac{0.86}{(\phi \cdot \beta)^{1 / 3}}-1\right] \\
& \phi_{0}=\frac{1}{\beta}\left[\frac{0.86}{\left(\mathrm{~S}_{0} / \mathrm{f} \cdot \mathrm{Dst}\right)+1}\right]^{3}
\end{aligned}
$$

ドラバーの補正が考慮されている。これによりラ ボ耐摩耗試験におけるCB最適配合量のアグリゲー 卜間距離を算出した結果，最適アグリゲート間距 離 $\mathrm{S}$ 。は20～23nmに集中することが報告されている (表 2 )。この結果は，配合系を問わずある一定の アグリゲート間距離 (21nm付近) で最適な耐摩耗 性を示すことを示唆している.

筆者らも種々のCBで同様の検討を行い, ほぼ近 似した結果を得ている ${ }^{15)}$ (一例を図11に示す)。こ の20数nmという距離は, $\mathrm{CB}$ 表面近傍の分子運動性 の少ないゴム層厚さが 5 ～ $8 \mathrm{~nm}$ であることを考慮す るとCBアグリゲート同士がこのゴム層に取り囲ま れた状態でファンデルワールスカが働くまで接近 した距離と一致している.すなわち, CBとのイン タラクションの強い低運動性ゴムに覆われたCB同 士が強固にスクラムを組み得る距離に相当し, そ の系で極限の耐摩耗性を発現するものと推察され る.このスクラムには隣り合ったアグリゲートの 複数にファンデルワールス吸着 (物理吸着), ある 


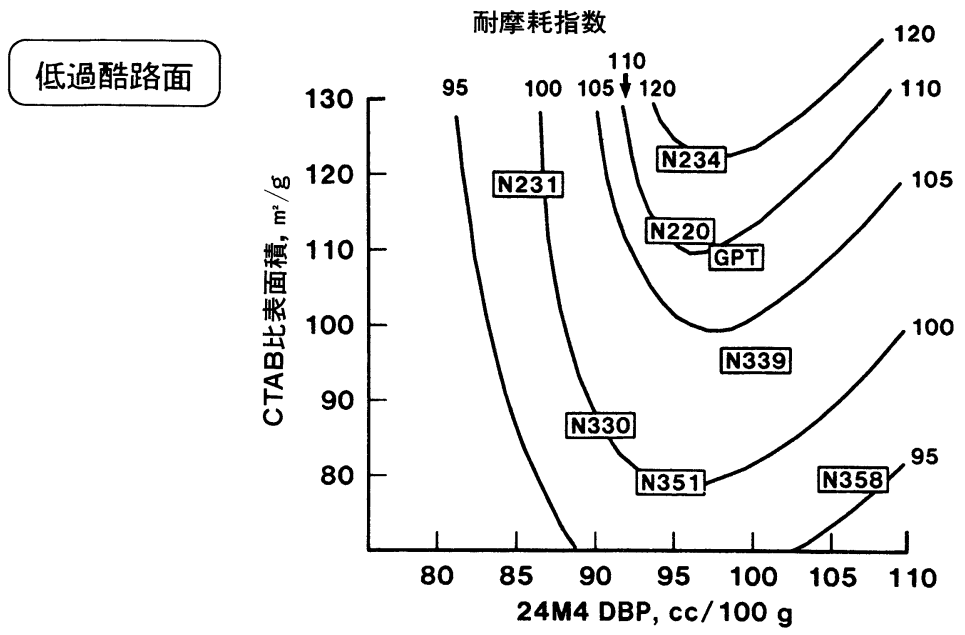

低シビリティ一路面（N330タイヤで $6336 \mathrm{~kg} / 1 \mathrm{~mm}$ 摩耗）でのN330に比較した耐摩耗指数

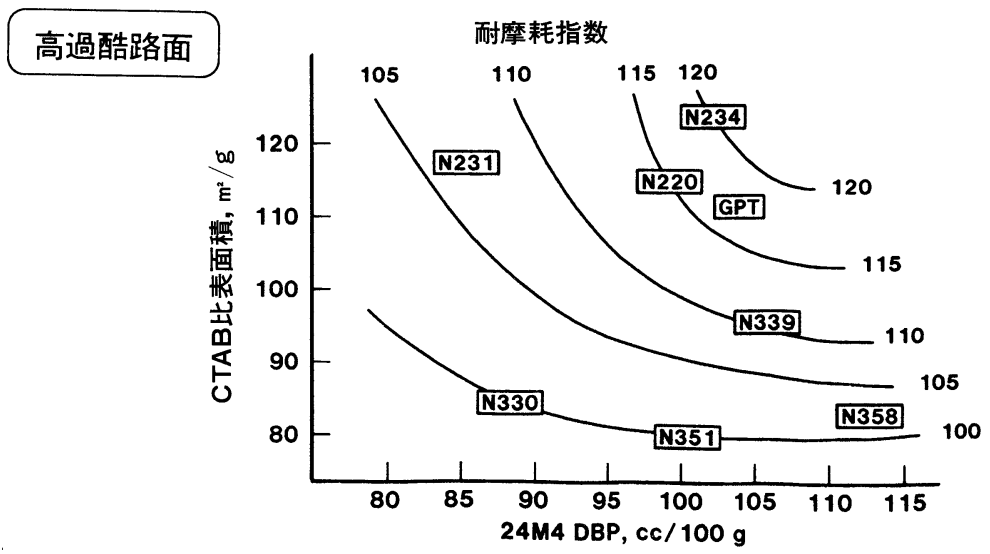

高シビリティー路面（N330夕イヤで $1330 \mathrm{~kg} / 1 \mathrm{~mm}$ 摩耗）でのN330に比較した耐摩耗指数 図 7 耐摩耗性に及ぼす一次粒子径とストラクチャーの影響

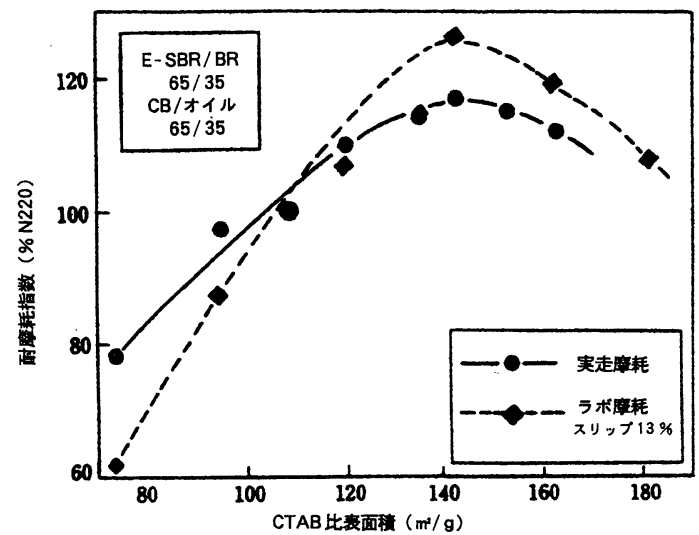

図 8 耐摩耗性に対するCB比表面積の影響

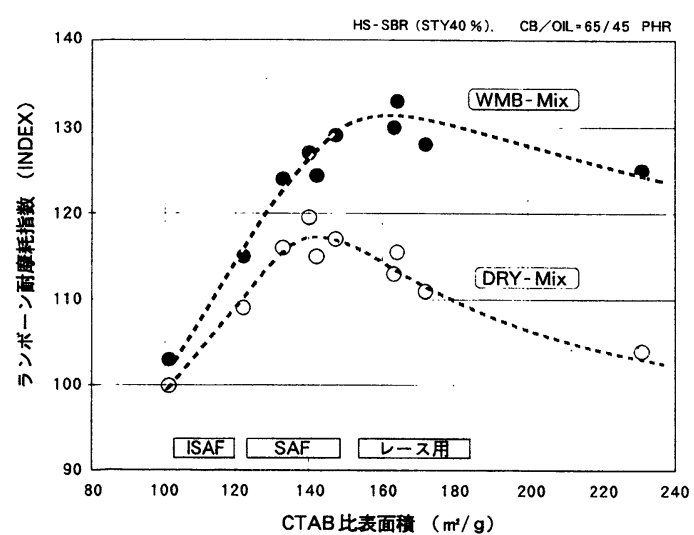

図 9 WMB-Mixの場合のCB比表面積〜耐摩耗性 


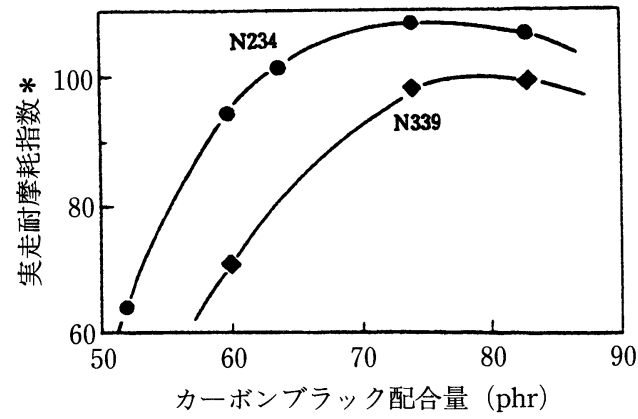

表 2 最適耐摩耗性を示すアグリゲート間距離 $\mathrm{S}_{0}$

SBR 1500を使用したトレッドコンパウント

\begin{tabular}{lccc} 
C. B. & $\begin{array}{c}\text { 最適 } \\
\text { phr }\end{array}$ & $\begin{array}{c}\text { 最適 } \\
\text { 容積分率 } \phi_{0}\end{array}$ & $\begin{array}{c}\mathrm{S}_{0} \\
(\mathrm{~nm})\end{array}$ \\
\hline $\mathrm{N} 110$ & 50 & 0.201 & 21.4 \\
$\mathrm{~N} 220$ & 52 & 0.206 & 23.2 \\
$\mathrm{~N} 339$ & 55 & 0.216 & 20.6 \\
$\mathrm{~N} 351$ & 57 & 0.230 & 21.8 \\
$\mathrm{~N} 326$ & 63 & 0.250 & 24.0 \\
\hline
\end{tabular}

図10 実走摩耗に対するCBの種類と配合量の影響
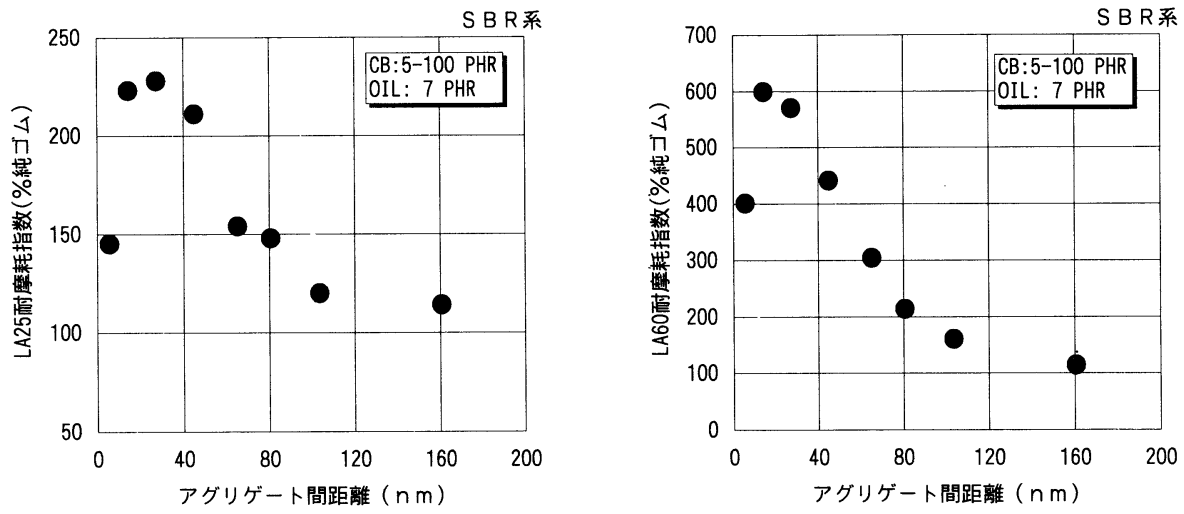

図11 アグリゲート間距離（計算値）とランボーン耐摩耗性の関係
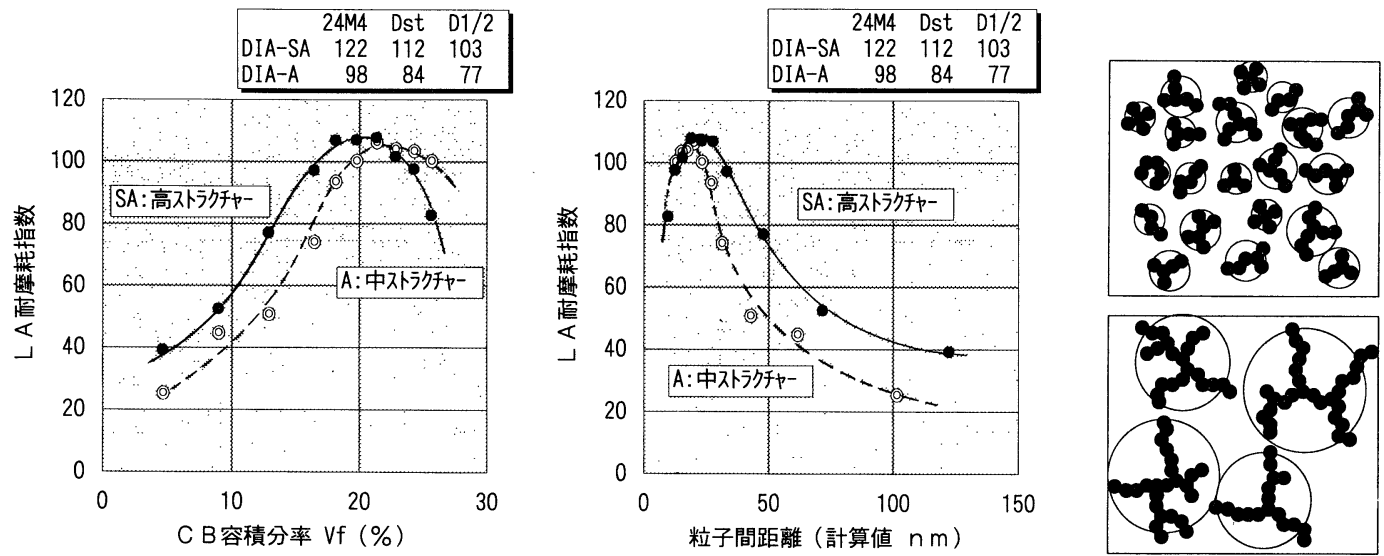

四12 ストラクチャーレベルの異なるCBと耐摩耗性 

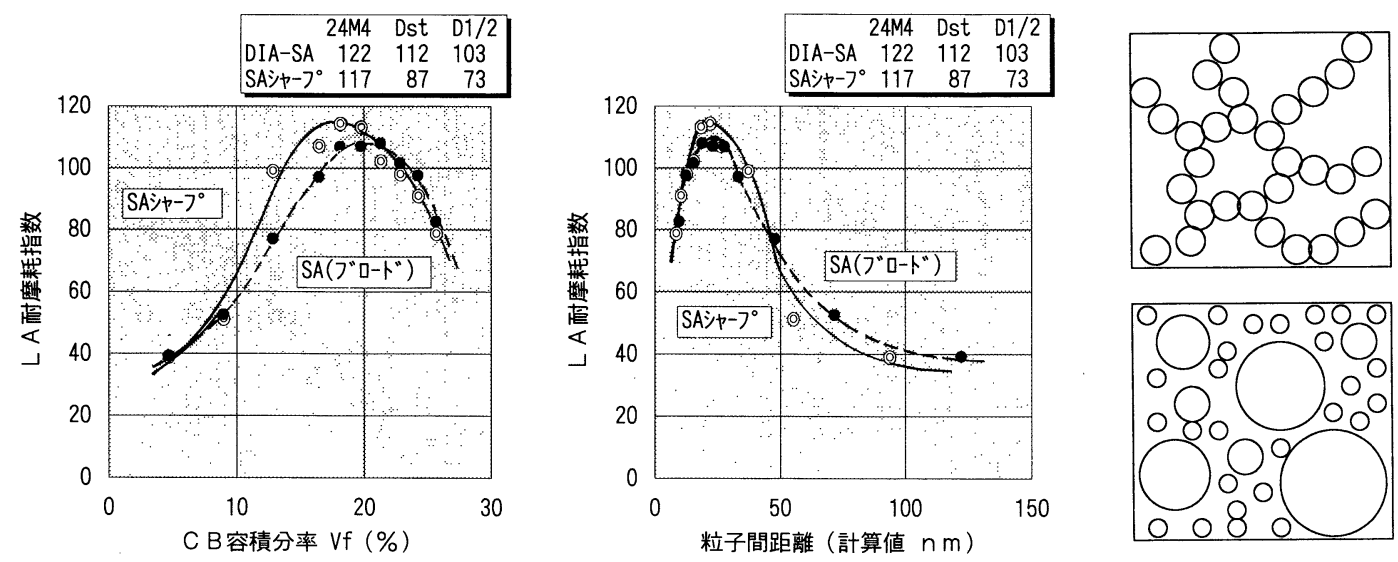

図13 アグリゲート径分布の異なるCBと耐摩耗性

いは結合したポリマー鎖も存在するであろう。な お，誌上ではあるがこの考察を「スクラムモデル」 として提案させていただきたい。率直な御意見, 御批判をお願いする次第である。

また, 図12はストラクチャーレベルの異なるCB の耐摩耗性データである。最適な耐摩耗性を示す CB容積分率は異なるが(図12左)，これをアグリゲ 一ト間距離でプロットするとピークはほぼ一致し た(図12右).今後はそれぞれのCBにとって最適耐 摩耗性を与えるCB配合量がある程度算出可能にな るであろう。

\section{2 アグリゲート形状・分布の影響}

CBアグリゲート径分布をブロードにすることに よりヒステリシスは低下する。これは分布がブロ 一ドなほどCBネットワークを形成しにくいためと 考えられる(図13右)。逆に分布がシャープになる と耐摩耗性は向上し, 最適耐摩耗性を示すCB容積 分率は低い側にシフトした(図13左)。この場合も アグリゲート間距離で整理するとピークはほぼ一 致した（図13中）.

このようにアグリゲート径分布がブロードにな ると耐摩耗性は低下寸る傾向にあるが, 高過酷度 下の場合には低下しないという報告例もある ${ }^{13)}$.ア グリゲート形状については 2 項で述べたように種々 の解析がなされている.SworらはN220クラスの高 ストラクチャー，かつ枝状比率の多いサンプルを 用いることにより, 同一Modulus配合で耐摩耗性／ ヒステリシスバランスを改良できると報告してい る16,17) (困14)。

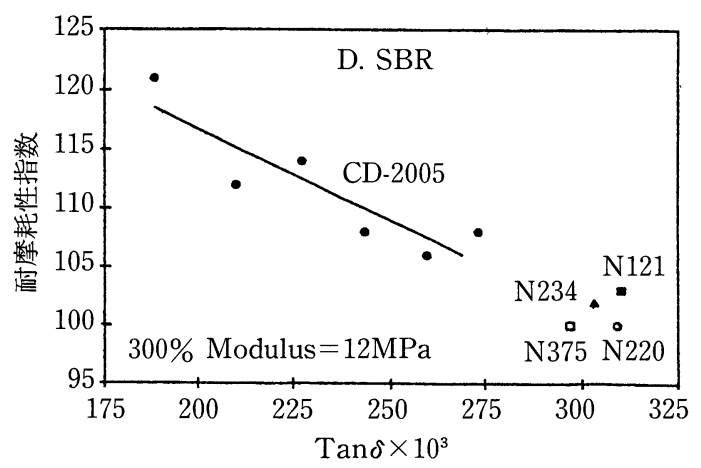

図14 同一モジュラス配合での耐摩耗性と $\tan \delta$

\section{3 表面性状の影響}

2 項で詳述したように最近の分析機器の進歩に よりCB表面の解析もかなり進んできた. Hessらは $\mathrm{CB}$ と耐摩耗性との関係についてバウンドラバー量 よりも水素量の方が相関が高いことを報告してい る ${ }^{18)}$ (図15). 図 4 から水素量の多いCBは活性点あ るいはエッジ部が多く，表面活性であることが判 る.このような $\mathrm{CB} は よ り \mathrm{CB} /$ ポリー間のインタ ラクションが強いものと推察される.

\section{4. ゴム配合物の摩擦に対するCBの影響}

タイヤの高性能化，および安全性の面からグリ ップ性やウェットスキッド性といったタイヤの摩 擦性能もますます重要となっている。一般にゴム の摩擦はAdhesion摩擦 (粘着摩擦) やHysteresis 摩擦（変形損失摩擦）等から成り立っていると考 

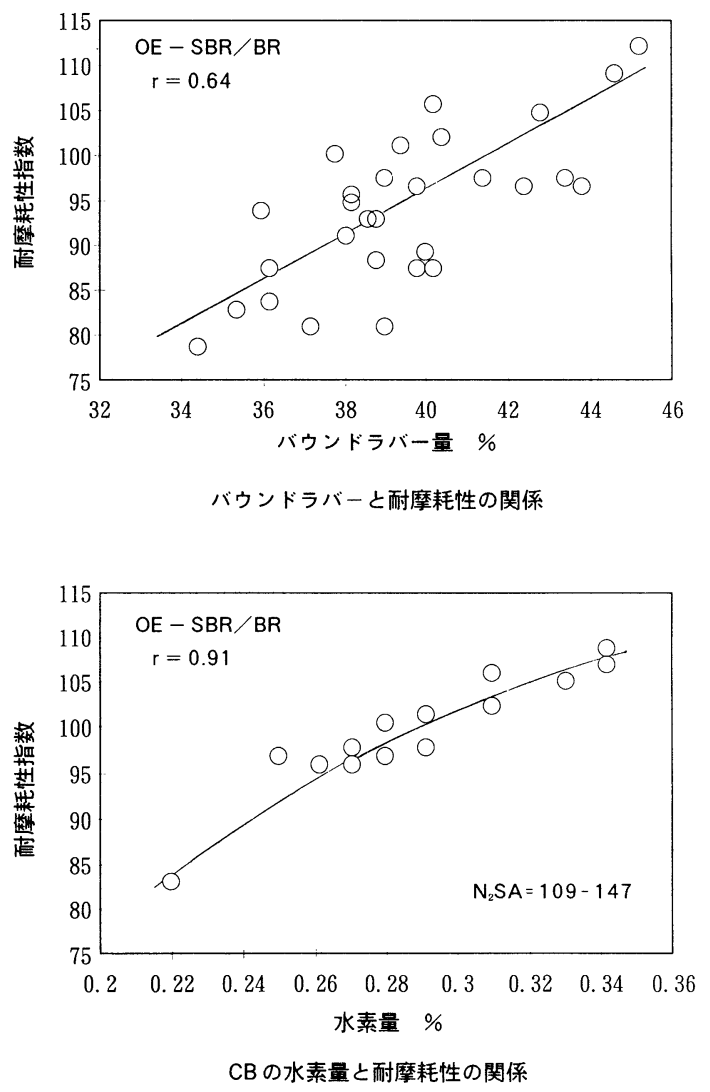

図15 CB表面活性度と耐摩耗性

えられている $\left(\mathrm{F}=\mathrm{F}_{\mathrm{adh}}+\mathrm{F}_{\mathrm{hys}}\right)$. Mooreはゴムの 粘弾性特性から摩擦を次のような式により表して いる ${ }^{19)}$.

$$
\begin{aligned}
& \mathrm{F}_{\mathrm{adh}}=\mathrm{k}_{1} \mathrm{~S}\left(\mathrm{E}^{\prime} / \mathrm{P}^{\mathrm{r}}\right) \tan \delta \\
& \mathrm{F}_{\mathrm{hys}}=\mathrm{k}_{2} \mathrm{~S}\left(\mathrm{P} / \mathrm{E}^{\prime}\right)^{\mathrm{n}} \tan \delta
\end{aligned}
$$

このように摩擦係数はtan $\delta の$ 関数として表すこ

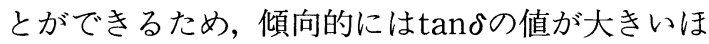
ど摩擦係数も高くなるということができる.

$\tan \delta$ CBの関係として,まずCaruthersらはtan $\delta$ がCBの容積分率の二乗と比表面積の積に比例する ことを報告している20)(図16). ただし，最近Funt らは比表面積が大きくなりすぎるとスキッドテス ターによる摩擦抵抗は改善されていないことを報 告している ${ }^{21)}$.これはCB分散悪化による凝集塊径 の増加と,摩擦抵抗にとってはCB/OIL量の方がよ り支配的になるためと説明している。

$\tan \delta$ を増大させる（すなわち摩擦係数 $\mu$ を大き

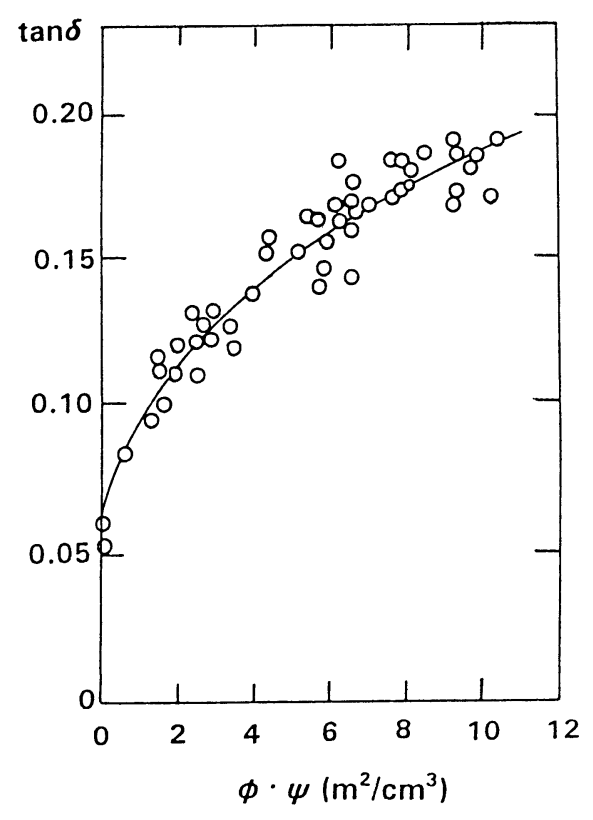

困16 $\phi \psi\left(=\phi^{2} \rho \mathrm{S}\right)$ と $\tan \delta の$ 関係

くする) $\mathrm{CB} の$ 基本特性の要因は, 冒頭の表 1 にま とめたとおりである.

最近, Ouyangらは振り子式スキッドテスターを 改良し，トレッドゴム配合物の摩擦特性を調べて いる ${ }^{22,23)}$. 摩擦係数 $\mu$ に及ぼすCB基本特性の影響は 接触路面の条件（種類, 乾き/濡れ, 温度）によ って異なり，これは摩擦メカニズムの違いに起因 するとしている. 各種条件下における， $\mu$ と相関の 高いラボ評価法, および硬度一定配合系での $\mu$ に及 ぼすCB特性, CB容積分率の影響を表 3 にまとめた。 実際の夕イヤに則した硬度一定配合系では高比表 面積, かつ高ストラクチャーCBを用いCB容積分率 を大きくすることが $\mu$ を増大させる方向であると述 べている.

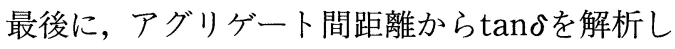
たデー夕を紹介する.Wangらはアグリゲート間距 離を求める式（前述の(1)式とは若干異なる）から 種々の系におけるアグリゲート間距離 $\delta_{\mathrm{a} a}$ を算出し,

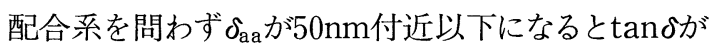
急激に上昇することを報告している ${ }^{24)}$ (図17)。こ の $\tan \delta の 上$ 昇はネットワーク形成により著しく加 速される。 
表 3 摩擦係数を増大させる方向とCB因子

\begin{tabular}{|c|c|c|c|c|}
\hline & & Wet摩擦 & 室温Dry摩擦 & 高温Dry摩擦 \\
\hline & 摩擦特性 & - & Cuttingの影響大 & Wearingの影響大 \\
\hline $\begin{array}{l}\text { ラ } \\
\text { ボ } \\
\text { 評 } \\
\text { 価 } \\
\text { 法 }\end{array}$ & $\begin{array}{l}\text { ロスコンプライアンス } \\
\text { 硬度 } \\
\text { 反ぱつ弾性 }\end{array}$ & $\begin{array}{l}\text { 圖相関大 } \\
\text { 低 } \\
\text { 低 }\end{array}$ & $\begin{array}{l}\text { 高 } \\
\text { 䢐相関大 } \\
\text { 低 }\end{array}$ & $\begin{array}{l}\text { 高 } \\
\text { 相関小 } \\
\text { 䢑相関大 }\end{array}$ \\
\hline $\begin{array}{l}\text { 硬 } \\
\text { 度 } \\
\text { 定 } \\
\text { 配 } \\
\text { 拿 }\end{array}$ & $\begin{array}{l}\text { CB一次粒子径 } \\
\text { CBストラクチャー } \\
\text { CB容積分率 } \\
\text { (オイル配合量) }\end{array}$ & $\begin{array}{l}\text { 小 } \\
\text { 高*) } \\
\text { 大 } \\
\text { (多) }\end{array}$ & $\begin{array}{l}\text { 小 } \\
\text { 高*) } \\
\text { 大 } \\
\text { (多) }\end{array}$ & $\begin{array}{l}\text { 丹効果大 } \\
\text { 高*) } \\
\text { 効果大 } \\
\text { (多) }\end{array}$ \\
\hline
\end{tabular}

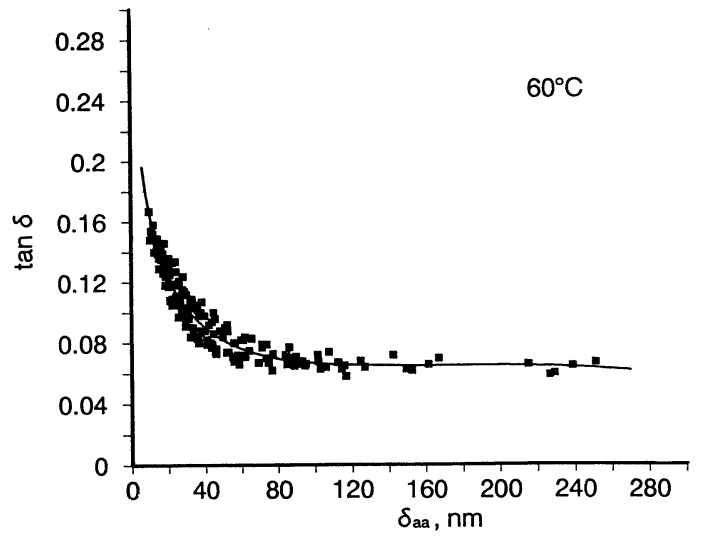

図17 アグリゲート間距離（計算値）と $\tan \delta$

\section{5.おわりに}

粒子分散系ゴムの耐摩耗性, 摩擦特性は系が複 雑であるために現象論的な知見が多い。しかし， 今回御紹介したようにCB表面, ゴムとのインタラ クション解析などもかなり進み本質が垣間見えて きた気もする.CBアグリゲート間距離からのアプ ローチも定量的解析を可能にし，今回CB／ゴム複 合体の相互作用を考察した「スクラムモデル」を 提案させて頂いた。 また前述の解析により, 耐摩 耗性や摩擦特性の予測可能性も示唆された。これ らを $\mathrm{CB}$ 設計にフィードバックしゴム製品の性能向 上に貢献することが我々メーカーの使命と考える. CBに要求される性能はトレードオフの関係が多い. ブレイクスルーには困難が伴うが，形状制御や表 面改質に次世代CBの可能性を感じる.
[付記］本稿は, 第44回ゴム技術シンポジウム (平 成 7 年 12 月 8 日）講演資料を基に一部加筆したも のである。

\section{引用 文 献}

1) Herd, C.R., McDonald, G.C., Hess, W.M. : Rubber Chem. Technol.', 65, 1 (1992)

2) Herd, C.R., McDonald, G.C., Hess, W.M. : Rubber Chem. Technol., 65, 107 (1992)

3) Herd, C.R., McDonald, G.C., Smith, R.E., Hess, W. M. : Rubber Chem. Technol., 66, 491 (1993)

4) Gerspacher, M., O'Farrell, C.P. : Kautsch. Gummi Kunstst., 45, 97 (1992)

5) Ehrburger-Dolle, F., Misono, S. : Carbon, 30 (1), 31 (1992)

6）曽根一祐：日ゴム協誌，68，635（1995）

7) Sone, K., Akimoto, H., Ishida, M. : Rubber World, 206, No.1, April 1992

8) Donnet, J.B., Custodero, E. : Carbon, 30, 813 (1992)

9) Donnet, J.B., Custodero, E. : Bull. Soc. Chim. Fr, 131, 115 (1994)

10) Donnet, J.B., Wang, T. K. : Proceeding of IRC '95, Kobe, 451 (1995)

11) Niedermeier, W., Raab, H., Stiersdorfer, J., Kreitmeier, S., Goritz, D. : Kautsch. Gummi Kunstst., 47, 799 (1994)

12）深堀美英：日ゴム協誌，68，605（1995）

13) Shieh, C.H., Mace, M.L., Ouyang, G.B., Branan, J. M., Juengel, R.R., Patterson, W.J., Funt, J.M. : Paper No.56 ACS Rubber Division 139th Meeting at Toront, Ontario, May 21-24, 1991

14) Tokita, N., Shieh, C.H., Ouyang, G.B., Patterson, W.J. : Kautsch. Gummi Kunstst., 47, 416 (1994)

15）三菱化学侏社内デー夕

16) Swor, R.A., Hess, W.M., Micek, E. : Elastomerics, 123, (3) 18 (1991)

17) Swor, R.A., Hess, W.M., Micek, E. : Elastomerics, 123, (4) 30 (1991)

18) Hess, W.M., Ayala, J.A., Vegvari, P.C., Kistler, F. D. : Kautsch. Gummi Kunstst., 41, 1215 (1988)

19) Moore, D.F. : The Friction and Lubrication of Elastomers, Pergamon Press, New York (1972)

20) Caruthers, J.M., Cohen, R.E., Medalia, A.I. : Rubber Chem. Technol., 49, 1076 (1976)

21) Funt, J.M., Shieh, C.H. : Kautsch. Gummi Kunstst., 42, 34 (1989)

22) Ouyang, G.B., Tokita, N., Shieh, C.H. : Paper No. 15 ACS Rubber Division 143rd Meeting at Denver, Colorado, May 18-21, (1993)

23) Ouyang, G.B., Tokita, N., Shieh, C. H. : Kautsch. Gummi Kunstst., 47, 633, 639 (1994)

24) Wang, M.J., Wolff, S., Tan, E.H. : Rubber Chem. Technol., 66, 178 (1993) 